\title{
Should Flexible Ureterorenoscopy be the First-line Treatment Option for Renal Calculi?
}

\author{
Flexible URS Böbrek Taşlarının Kırılmasında Illk Seçenek mi olmalıdır?
}

\author{
Zafer Turkyilmaz ${ }^{1}$, Kaan Sonmez ${ }^{1}$, Ramazan Karabulut ${ }^{1}$, Fazli Polat ${ }^{2}$, Suleyman Yesil ${ }^{2}$, Sibel Eryilmaz ${ }^{1}$, Vokhid Tairov $^{3}$ \\ A.Can Basaklar ${ }^{1}$
}

\footnotetext{
${ }^{1}$ Gazi University Faculty of Medicine Department of Pediatric Surgery, Ankara, Turkey

${ }^{2}$ Gazi University Faculty of Medicine Department of Urology, Ankara, Turkey

${ }^{3}$ Ahmet Yesevi University, Faculty of Medicine Department of Pediatric Surgery, Turkistan, Kazakhstan
}

\begin{abstract}
While first-line treatment option for pediatric renal calculi, $1.5-2 \mathrm{~cm}$ in size, was open surgery in the past, percutaneous nephrolithotomy (PNL) is now the first-line treatment option in accordance with EUA pediatric guidelines. However, mini rigid ureterorenoscopy (URS) and the laser props of flexible URS have started to be used in the removal of these calculi. The present study aimed at conveying our experience in using flexible URS and laser on the removal of right renal calculus, $16 \mathrm{~mm}$ in size, in a 1-year-old male pediatric patient.
\end{abstract}

Key Words: Flexible ureterorenoscopy, laser lithotripter, renal calculi, children

Received: 11.28 .2016
Accepted:04.25.2017
ÖZET

Boyutu 1.5-2 cm arasında olan böbrek taşı şikayeti ile başvuran çocuklarda eskiden ilk seçenek açık cerrahi iken günümüzde ilk tercih EUA pediatrik kılavuzuna göre Perkütan Nefrolitotomi (PNL) dir. Fakat mini rigid üreterorenoskop (URS) ve fleksible URS'nin laser proplarıla beraber bu tip taşların kırılmasında kullanılmaya başlamıştır. Biz de bu sunum ile sağ böbreğinde $16 \mathrm{~mm}$ lik taşı olan 1 yaş erkek çocuktaki taşın kırılmasında fleksible URS ve laser kullanma deneyimimizi aktarmak istedik.

Anahtar Sözcükler: Fleksible üreterorenoskop, laser taşkırıcı, böbrek taşı, çocuklar

Geliş Tarihi: $\quad 28.11 .2016$

Kabul Tarihi:25.04.2017

\section{INTRODUCTION}

Turkey is one of the endemic countries in terms of urolithiasis. Pediatric patients can sometimes present with renal calculi, $1.5-2 \mathrm{~cm}$ in size, without any underlying metabolic or anatomical reasons. While first-line treatment option for these patients was open surgery in the past, percutaneous nephrolithotomy (PCNL) is now the first-line treatment option in accordance with EUA pediatric guidelines (1). However, in parallel with the rapid advancements in modern-day technology, it seems that the ranking of treatment options will change with the use of mini rigid ureterorenoscopy (URS) and the laser props of flexible URS. It was our aim in this study to share the success we achieved by using flexible URS in the removal of right renal calculus, $16 \mathrm{~mm}$ in size, in a 1-year-old male pediatric patient.

\section{CASE REPORT}

A 12-month-old male pediatric patient, who had suffered from ongoing urinary tract infection and change in urine color since he was 6 months old, applied to our clinic upon having had detected two kidney stones, the largest of which was $16 \mathrm{~mm}$, in the right kidney ureteropelvic (UP) junction and grade 2 hydronephrosis. It was found out that open nephrolithotomy or percutaneous nephrolithotomy (PCNL) was suggested in the first center the patient applied to, and the parents of the patient refused these procedures, and thus, came to our clinic. All biochemical and metabolic analyses of the patient towards nephrolithiasis etiology were normal and the patient did not have any anatomical anomalies. 
Patient and family histories were found normal. The procedure was performed with the patient placed in lithotomy position using $7.5 \mathrm{~F}$ flexible ureteroscope (Karl Storz, Tutlingen, Germany). Initially, semi-rigid URS or cystoscopy was performed in order to place the hydrophilic guidewires into the renal collecting system. The flexible ureteroscope or semi-rigid URS was not introduced into the ureter and renal collecting system, double $\mathrm{j}$ (dj) stent was placed, and the procedure was repeated three weeks later. Ureteral access sheath was not used in this patient. Ureteral orifice dilation was not performed and a radiation-free operation was conducted. Staghorn stone was determined in the right kidney UP junction, filling the pelvis. A holmium:yttrium-aluminum-garnet (Ho-YAG) laser was used as lithotripter. Laser energy and frequency were $1.0 \mathrm{~J}$ and $6 \mathrm{~Hz}$, respectively. Stone extraction was not performed routinely, especially fragments smaller than $4 \mathrm{~mm}$ were left to pass spontaneously to reduce operative time. A dj stent (3f) was placed in the collecting system and the operative time was 40 minutes. During dj stent extraction three weeks later, the remaining $4 \mathrm{~mm}$ stone was removed in the same manner with flexible URS. The patient was discharged with recommendations. There were no stones detected on third month follow-up USG. The patient was followed up with urine analysis and urinary USG, no stones were detected on sixth month follow-up.

\section{DISCUSSION}

Turkey can be accepted as endemic in comparison to other European countries as regards urolithiasis. According to EUA pediatric guidelines at the present time, while first-line treatment option in stones smaller than $1 \mathrm{~cm}$ is flexible URS, first-line treatment option in stones larger than $1.5 \mathrm{~cm}$ is PCNL(1,2). PCNL may present problems in infants and preschool-age children due to the small size and mobility of the pediatric kidney, friable renal parenchyma, and the small size of the collecting system. Retrograde intrarenal surgery (RIRS) can be preferred for small-volume, non-staghorn stones since it generates good outcomes and there is no need for open surgery or PCNL $(3,4)$. However, most of those reports include a significant number of older adolescents. Stone disease in pediatric patients at a very young age is often associated with anatomical and metabolic abnormalities or infectious diseases, and the risk of recurrence is high (5). These factors make minimally invasive procedures more important in this age group. Therefore, flexible URS, the least invasive method for the kidney and the child in this age group, can be preferred over PCNL. In a series by Citamak and colleagues, examining 294 patients (346 renal units) with a mean age of $8.51 \pm 4.91$ years, hemorrhage at a rate of $11.8 \%$, urinary infection at a rate of $6 \%$, urosepsis and hydrothorax at a rate of $0.1 \%$ have been observed and one patient have been lost during PNL(6). Saad and colleagues have compared RIRS (21) and PCNL (22) in stones larger than $2 \mathrm{~cm}$ in a total of 38 pediatric patients (43 renal units) under the age of 16 , and length of hospital stay, radiation quantity $(p<0.001)$, and complications $(p=0.018)$ have been found high and there has been the need for blood transfusion in 3 patients $(p=0.015)(7)$. In a mini PCNL series by Daw et al., bleeding $(8 \%)$, hematuria and blood transfusion $(4 \%)$, renal pelvis perforation (4\%), leakage (8\%), and fever (15\%) have been seen(8). Two randomized and eight non-randomized studies were analyzed. It was observed that PCNL techniques ensured a significantly higher stone-free rate but also higher complication rates $(p<0.01)$ and a larger postoperative decrease in hemoglobin levels $(p<0.00001)$. In contrast, RIRS led to shorter hospital stay $(p<0.0001$ ) (9). A total of 65 patients with a mean age of $4.31 \pm 1.99$ years ( 6 months -7 years) have been included in a flexible URS series by Erkurt et al conducted on pre-school children. Mean stone size and mean operative time were $14.66 \pm 6.12 \mathrm{~mm}(7-30 \mathrm{~mm})$ and $46.47 \pm 18.27 \mathrm{~min}$, respectively. In 5 (7.69\%) patients, the initial procedure failed to reach the renal collecting system and ended with the insertion of a pigtail stent. Stone-free rates were 83.07 and $92.3 \%$ after the first and second procedures, respectively. Postoperative hematuria developed in $6(9.2 \%)$ patients, post-operative urinary tract infection with fever was encountered in 10 (15.4\%) patients, and ureteral wall injury was seen in $2(3 \%)$ patients (10). A total of 16 patients (9 boys and 7 girls; mean age, 4.2 years) have undergone 17 procedures in a series by Ünsal et al., mean stone size was $11.5 \mathrm{~mm}(8-17 \mathrm{~mm})$. Flexible URS and laser lithotripsy were performed in all cases. Ureteral orifice was required to be dilated in 5 cases (29.4\%) and ureteral access sheaths were placed in 3 (17.6\%). With a mean follow-up of 10.3 months, $88 \%$ of the children were stone free. The success rate for stones smaller than $10 \mathrm{~mm}$ was $100 \%$ and $81.8 \%$ for stones $10 \mathrm{~mm}$ or larger in size $(p<0.05)$. There were no major complications, but there was 1 case of perforation and extravasation at the ureterovesical junction after balloon dilation, which was managed with stent placement $(3,5)$. However, both access sheath was used and ureteral dilation was performed on these last two series, and the patients were exposed to radiation.
Alongside the increase in the use of flexible URS and the start of its use on renal calculi, the fact that its laser prop used to break the stones is small in size and bendable with flexible URS is an indicator that flexible URS is moving towards becoming the first-line treatment option for renal calculi no matter the size. Apart from treating the stone in this case, while we both provided economic gain and reduced the possibility of complications like vesicoureteral reflux and perforation by not using access sheath necessary for the dilation in the breaking of the stones in pediatric patients, we also protected the patient and the physician from rays by working radiation free.

\section{CONCLUSION}

Flexible URS should be opted for as first-line treatment in suitable cases of pediatric renal calculi due to the fact that it is repeatable, easy to be used, does not require rays and does not harm the renal unit.

\section{Conflict of interest}

No conflict of interest was declared by the authors.

\section{REFERENCES}

1. Urinary Stone Disease. Tekgul S, Dogan HS, Hoebeke P, et al. European Association of Paediatric Urology Guidelines, 2016 Edition, 58-65.

2. Dogan HS, Onal B, Satar N, et al. Factors affecting complication rates of ureteroscopic lithotripsy in children: results of multiinstitutional retrospective analysis by Pediatric Stone Disease Study Group of Turkish Pediatric Urology Society. J Urol 2011; 186:1035-40.

3. Unsal A, Resorlu B. Retrograde intrarenal surgery in infants and preschool-age children. J Pediatr Surg 2011; 46: 2195-9.

4. Dave $S$, Khoury AE, Braga $L$, et al. Single-institutional study on role of ureteroscopy and retrograde intrarenal surgery in treatment of pediatric renal calculi. Urology 2008;72: 1018-21.

5. Unsal A, Resorlu B, Kara C, et al. Safety and efficacy of percutaneous nephrolithotomy in infants, preschool age, and older children with different size of instruments. Urology 2010; 76: 24753.

6. Çıtamak B, Altan M, Bozacl AC, et al. Percutaneous Nephrolithotomy in Children: 17 Years of Experience. J Urol 2016; 195(4P1):1082-7.

7. Saad KS, Youssif ME, Al Islam Nafis Hamdy S, et al. Percutaneous Nephrolithotomy vs Retrograde Intrarenal Surgery for Large Renal Stones in Pediatric Patients: A Randomized Controlled Trial. J Urol 2015; 194: 1716-20.

8. Daw K, Shouman AM, Elsheemy MS, et al. Outcome of Minipercutaneous nephrolithotomy for Renal Stones in Infants and Preschool Children: A Prospective Study. Urology 2015; 86:101926.

9. Zhang W, Zhou T, Wu T, et al. Retrograde Intrarenal Surgery Versus Percutaneous Nephrolithotomy Versus Extracorporeal Shockwave Lithotripsy for Treatment of Lower Pole Renal Stones: A MetaAnalysis and Systematic Review. J Endourol 2015; 29:745-59.

10. Erkurt B, Caskurlu T, Atis G, et al. Treatment of renal stones with flexible ureteroscopy in preschool age children. Urolithiasis 2014;42: 241-5. 